\title{
Basal Cell Carcinoma Disguised Among Intradermal Nevi
}

\author{
Gabriel Salerni ${ }^{1,2}$ \\ 1 Dermatology Department, Hospital Provincial del Centenario de Rosario - Universidad Nacional de Rosario, Argentina \\ 2 Oroño Medical Diagnosis, Rosario, Argentina
}

Citation: Salerni G. Basal cell carcinoma disguised among intradermal nevi. Dermatol Pract Concept. 2022;12(1):e2022028. DOI: https://doi.org/10.5826/dpc.1201a28

Accepted: July 1, 2021; Published: January 2022

Copyright: (02022 Gabriel Salerni. This is an open-access article distributed under the terms of the Creative Commons Attribution-NonCommercial License (BY-NC-4.0), https://creativecommons.org/licenses/by-nc/4.0/, which permits unrestricted noncommercial use, distribution, and reproduction in any medium, provided the original authors and source are credited.

Funding: None.

Competing interests: None.

Corresponding author: Gabriel Salerni, MD, PhD, Dermatology Department, Hospital Provincial del Centenario de Rosario - Universidad Nacional de Rosario, Argentina; Oroño Medical Diagnosis, Rosario, Argentina. E-mail: gabrielsalerni@hotmail.com

\section{Case Presentation}

A 61-year-old woman presented to consultation for routine skin examination. Cutaneous examination revealed multiple longstanding firms, achromic, dome-shaped, papules, ranging from $5 \mathrm{~mm}$ to $12 \mathrm{~mm}$ in diameter (Figure 1A) located on the forehead. The patient was unaware of any change. Dermoscopy revealed remnants of light brown pigmentation, terminal hairs, comma-like (linear curved) vessels and comedo-like openings in lesions a to e (Figure $1 \mathrm{~B}$ ) which were suggestive of intradermal nevi. Lesion $\mathrm{f}$ displayed dermoscopic criteria for basal cell carcinoma consisting of a pink background, arborizing telangiectasias, gray-brown dots, and structureless areas.

\section{Teaching Point}

Dermoscopy improves the diagnosis of non-pigmented skin tumors because it allows the visualization of vascular patterns and residual pigmentation that are not visible to the naked eye $[1,2]$. In this case, dermoscopy provided crucial information for recognition of a basal cell carcinoma that might have been overlooked among multiple benign melanocytic lesions assessed solely by the naked eye.

Informed consent: Informed consent for publication of clinical details and clinical images was obtained from the patient. 


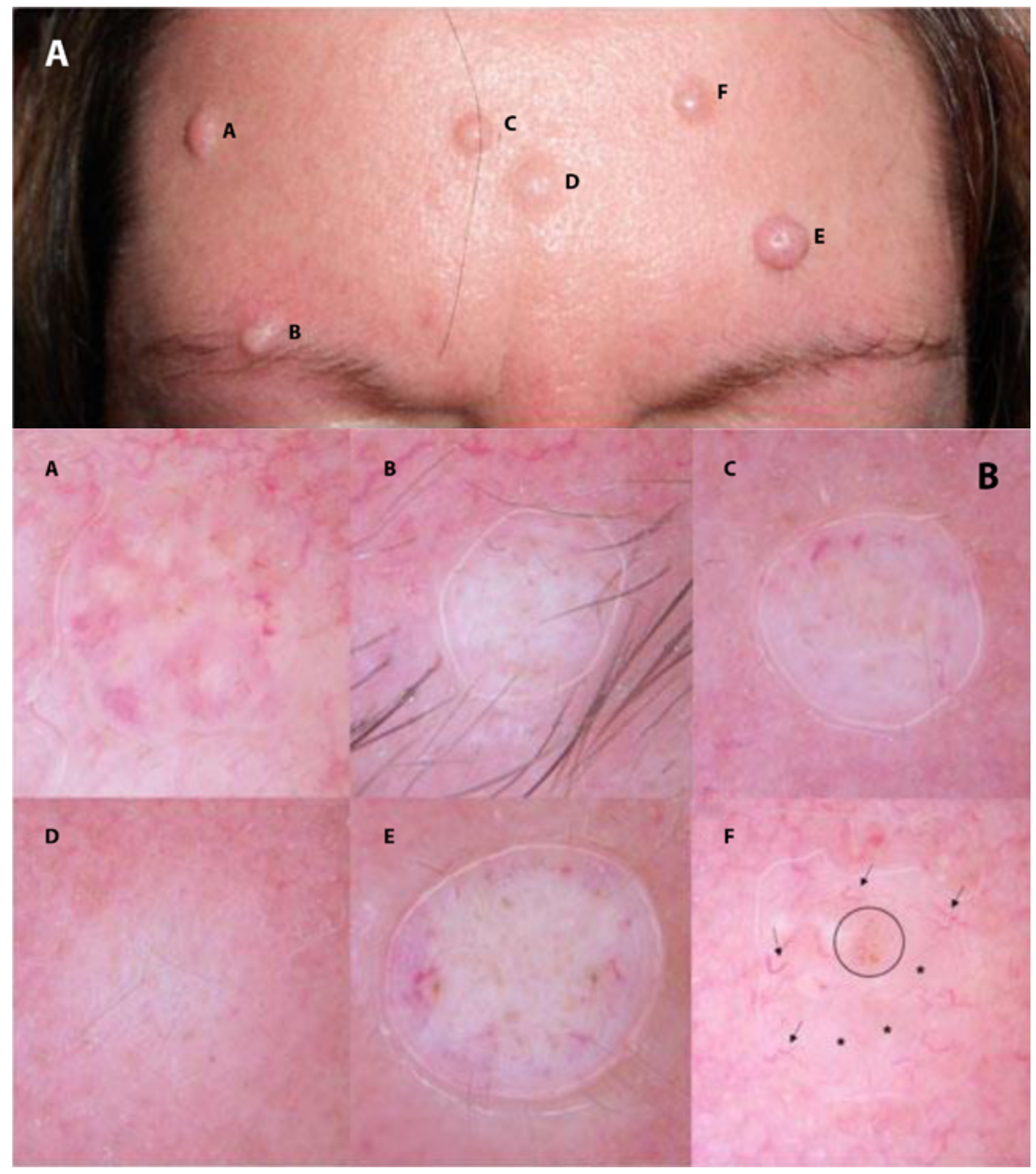

Figure 1. (A) Multiple firms, achromic, dome-shaped papules, located on the forehead. (B) Dermoscopy revealed criteria for intradermal nevi in lesions a to e, while lesion $\mathrm{f}$ displayed pink background, arborizing telangiectasias (arrows), gray-brown dots (circle), and structureless areas (asterisks) consistent with basal cell carcinoma.

\section{References}

1. Zalaudek I, Kreusch J, Giacomel J, Ferrara G, Catricalà C, Argenziano G. How to diagnose nonpigmented skin tumors: a review of vascular structures seen with dermoscopy: part I. Melanocytic skin tumors. J Am Acad Dermatol. 2010;63(3):361-74; quiz 375-6. DOI: 10.1016/j.jaad.2009.11.698. PMID: 20708469.

2. Greco V, Cappello M, Megna M, et al. Dermoscopic patterns of intradermal naevi. Australas J Dermatol. 2020;61(4):337-341. DOI: 10.1111/ajd.13366. PMID: 32715462. 